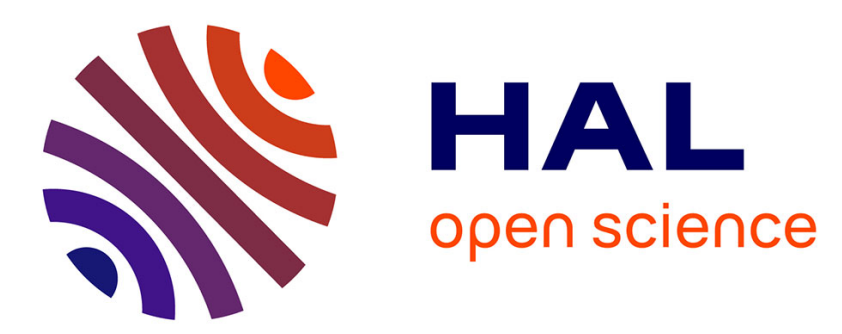

\title{
The potential for monitoring and control of insect pests in Southern Hemisphere forestry plantations using semiochemicals
}

Ryan Nadel, Michael Wingfield, Mary Scholes, Simon Lawson, Slippers

\section{- To cite this version:}

Ryan Nadel, Michael Wingfield, Mary Scholes, Simon Lawson, Slippers. The potential for monitoring and control of insect pests in Southern Hemisphere forestry plantations using semiochemicals. Annals of Forest Science, 2012, 69 (7), pp.757-767. 10.1007/s13595-012-0200-9 . hal-00930849

\section{HAL Id: hal-00930849 \\ https://hal.science/hal-00930849}

Submitted on 1 Jan 2012

HAL is a multi-disciplinary open access archive for the deposit and dissemination of scientific research documents, whether they are published or not. The documents may come from teaching and research institutions in France or abroad, or from public or private research centers.
L'archive ouverte pluridisciplinaire HAL, est destinée au dépôt et à la diffusion de documents scientifiques de niveau recherche, publiés ou non, émanant des établissements d'enseignement et de recherche français ou étrangers, des laboratoires publics ou privés. 


\title{
The potential for monitoring and control of insect pests in Southern Hemisphere forestry plantations using semiochemicals
}

\author{
Ryan L. Nadel • Michael J. Wingfield • \\ Mary C. Scholes • Simon A. Lawson • Bernard Slippers
}

Received: 1 August 2011 / Accepted: 27 February 2012 / Published online: 22 March 2012

(C) INRA / Springer-Verlag France 2012

\begin{abstract}
- Context Southern Hemisphere plantation forestry has grown substantially over the past few decades and will play an increasing role in fibre production and carbon sequestration in future. The sustainability of these plantations is, however, increasingly under pressure from introduced pests. This pressure requires an urgent and matching increase in the speed and efficiency at which tools are developed to monitor and control these pests.

- $\operatorname{Aim}$ To consider the potential role of semiochemicals to address the need for more efficient pest control in Southern Hemisphere plantations, particularly by drawing from research in other parts of the world.
\end{abstract}

Handling Editor: Francois Lieutier

Contributions of co-authors R.L. Nadel wrote the paper and analysed the data, as it formed part of his PhD project.

R. L. Nadel · M. J. Wingfield · B. Slippers $(\bowtie)$

Department of Genetics, Forestry and Agricultural Biotechnology

Institute (FABI), University of Pretoria,

Pretoria 0002, South Africa

e-mail: Bernard.Slippers@fabi.up.ac.za

M. C. Scholes

School of Animal, Plant and Environmental Sciences,

University of the Witwatersrand,

Private Bag 3,

Wits 2050, South Africa

\section{S. A. Lawson}

Department of Employment, Economic Development and Innovation and University of the Sunshine Coast,

Ecosciences Precinct, GPO Box 267, Brisbane, QLD 4001,

Australia

Present Address:

R. L. Nadel

Institute for Commercial Forestry Research (ICFR),

P.O. Box 100281, Scottsville, Pietermaritzburg 3209, South Africa
- Results Semiochemical research in forestry has grown exponentially over the last 40 years but has been almost exclusively focussed on Northern Hemisphere forests. In these forests, semiochemicals have played an important role to enhance the efficiency of integrated pest management programmes. An analysis of semiochemical research from 1970 to 2010 showed a rapid increase over time. It also indicated that pheromones have been the most extensively studied type of semiochemical in forestry, contributing to $92 \%$ of the semiochemical literature over this period, compared with research on plant kairomones. This research has led to numerous applications in detection of new invasions, monitoring population levels and spread, in addition to controlling pests by mass trapping or disrupting of aggregation and mating signals.

- Conclusion The value of semiochemicals as an environmentally benign and efficient approach to managing forest plantation pests in the Southern Hemisphere seems obvious. There is, however, a lack of research capacity and focus to optimally capture this opportunity. Given the pressure from increasing numbers of pests and reduced opportunities to use pesticides, there is some urgency to develop semiochemical research capacity.

Keywords Pheromone $\cdot$ Kairomone $\cdot$ Pest management $\cdot$ Forest entomology $\cdot$ Forest plantations

\section{Introduction}

Large volumes of wood and fibre are produced in the Southern Hemisphere and tropics from non-native tree species cultivated in intensively managed forestry plantations 
(Sedjo 1999; FAO 2007, 2011). As greater areas of natural forests are being set aside for conservation, a larger proportion of the worlds wood supply is expected, in the next few decades, to come from planted forest plantations (Sedjo 2000; Carle and Holmgren 2008; FAO 2011). The high productivity and rapid growth that is achieved in many of these plantations of the Southern Hemisphere and tropics is in part due to the absence of damage to these trees by pests and diseases (Wingfield 2003; Wingfield et al. 2008). As a consequence, one of the greatest threats to fibre production in plantations of non-native trees arises from newly emerging pests and pathogens (Wingfield et al. 2008). Nonindigenous insect pests are introduced largely through international trade and travel (Work et al. 2005; Smith et al. 2007; Roques et al. 2008; Brockerhoff et al. 2006b). Assuming that conditions are favourable, they can become established extremely rapidly (Bartell and Nair 2004; Kolar and Lodge 2001; Peacock and Worner 2008; Wilson et al. 2009). Free from their natural enemies, and sometimes challenged by fewer environmental limitations, these pest populations can build up uncontrollably. The ultimate outcome can be substantial economic losses for forestry companies as a result of reduced tree growth or increased tree mortality. In this way, invasives threaten the future sustainability of these important economic and ecological resources.

Several approaches are used to control invasive pests in non-native forest plantations in the tropics and Southern Hemisphere. Silvicultural management has been effective in many cases, but it is not practical or effective for all insect pests (Carnegie et al. 2005; Stone 2001). Classical biological control has been extensively used in agriculture and non-native plantation forestry but with varying levels of success (DeBach 1974; Hurley et al. 2007; Bale et al. 2008). An accepted, but less desirable, short-term alternative to reduce pest populations rapidly is through the application of pesticides. Pesticides, however, have many negative impacts on the environment, including the continuing need for mass spraying that also has negative effects on beneficial insects and other non-target organisms (Pimentel et al. 1992).

Semiochemicals represent a key component of many integrated pest management (IPM) programs for forestry pests in the Northern Hemisphere (Otvos and Shepherd 1991; Goyer 1991; Lindgren and Fraser 1994; Leonhardt et al. 1996; Hosking et al. 2003; Asaro et al. 2004; Faccoli and Stergulc 2008; Norin 2001; Clarke 2001). They are particularly considered as efficient tools to monitor or reduce pest populations. They have, however, rarely been used in the Southern Hemisphere for these purposes. In this review, we argue that semiochemicals should be a key component of future plantation forest sustainability in the tropics and Southern Hemisphere.

\section{Semiochemicals research and use to manage forest pests in the Northern Hemisphere}

\subsection{Analysis of semiochemical research}

Semiochemical research in forestry has increased exponentially over the last 40 years. A search of the ISI Web of Knowledge, Web of Science databases (March 2010) for all scientific publications with the keywords: forest* AND (semiochemical* OR pheromone* OR kairomone* OR allelochemical ${ }^{*}$ ), revealed 429 publications between 1970 and 2009. The rise in the number of publications since 1970 is linked to the fact that semiochemicals were discovered and first synthesized in the 1960s after 22 years of research (Kelly 1990) and in addition, the inauguration of the Journal of Chemical Ecology in March 1975. The increased availability of scientific equipment and significant technological advances in semiochemical identification and synthesis has resulted in a substantial increase in research on the topic since 1990.

Pheromones are by far the most studied semiochemicals in forestry, contributing to $92 \%$ of the 429 forestry and semiochemical-related scientific papers. The majority of pheromone research (30\%) has been conducted on Coleopterans, with Lepidopteran pests of forest trees constituting the second most abundant group (24\%). Aggregation pheromones, for example, play an important role in sustaining insect attack and infestation levels (Hughes 1974; Silverstein 1981; Wood 1982; Vité and Baader 1990; Schlyter et al. 2001), especially of bark beetles. Sex pheromones have also been widely used for mass trapping and mating disruption to suppress various pests, especially relevant to the Lepidoptera (Fitzgerald 2008; Norin 2001; Thorpe et al. 1999; Silverstein 1981). Research on plant-derived semiochemicals such as volatile organic compounds can aid in plant protection but are often less specific and can be complex to dissect and apply. Consequently, this is an area of research that has received less attention. In a forestry context, protection through plant-derived semiochemicals has focussed on the development of kairomone lures that attract and monitor insect pests such as Coleopterans in Pinus and Populus forests (Gallego et al. 2008; Miller 2006; Borden et al. 1998; Sun et al. 2003).

\subsection{Monitoring}

One of the most important applications of semiochemicals in forest pest control lies in monitoring the spread and population levels of the target insect (Table 1). Monitoring can be done with either kairomone (an allelochemical that benefits the receiver) or pheromone baits in a variety of traps and for different insect orders. Kairomone traps have most commonly been used to monitor bark beetle populations. Several 
Table 1 Examples of semiochemical research and application for monitoring of pests in forestry and other environments (e.g. urban high-risk entry points)

\begin{tabular}{|c|c|c|c|}
\hline Insect $^{\mathrm{a}}$ & Family & Country & Reference \\
\hline \multicolumn{4}{|l|}{ Coleoptera } \\
\hline Bark and wood boring insects ${ }^{\mathrm{a}}$ & $\begin{array}{l}\text { Mainly Scolytidae, } \\
\text { Platypodidae, } \\
\text { Ceramabycidae, } \\
\text { Buprestidae, } \\
\text { Siricidae } \\
\text { Cerambycidae }\end{array}$ & $\begin{array}{l}\text { New Zealand, Australia } \\
\text { and USA }\end{array}$ & $\begin{array}{l}\text { (Wylie et al. 2008; Miller 2006; Bashford } \\
\text { 2008; Brockerhoff et al. 2006a; Costello } \\
\text { et al. 2008) }\end{array}$ \\
\hline Monochamus alternatus & & Japan & (Nakamura et al. 1999) \\
\hline M. galloprovincialis & & Spain & (Pajares et al. 2004; Ibeas et al. 2007) \\
\hline Anaglyptus subfasciatus & & Japan & (Nakamuta et al. 1997) \\
\hline Tetropium castaneum & & Canada & (Sweeney et al. 2006) \\
\hline T. cinnamopterum & & Canada & (Sweeney et al. 2006) \\
\hline \multirow[t]{2}{*}{ Tetropium fuscum } & & Canada & (Sweeney et al. 2006) \\
\hline & Chrysomelidae & & \\
\hline \multirow[t]{2}{*}{ Chrysomela scripta } & & USA & (Kendrick and Raffa 2006) \\
\hline & Cleridae & & \\
\hline Thanasimus dubius & & USA & (Erbilgin and Raffa 2002) \\
\hline \multirow[t]{2}{*}{ T. formicarius } & & Sweden & (Schlyter and Lundgren 1993) \\
\hline & Curculionidae & & \\
\hline Pissodes nemorensis $^{\mathrm{a}}$ & & USA & (Rieske 2000) \\
\hline \multirow[t]{2}{*}{ Hylobius pales ${ }^{\mathrm{a}}$} & & USA & (Rieske 2000) \\
\hline & Histeridae & & \\
\hline Platysoma cylindrical & & USA & (Erbilgin and Raffa 2002) \\
\hline \multirow[t]{2}{*}{ P. parallelum } & & USA & (Erbilgin and Raffa 2002) \\
\hline & Platypodidae & & \\
\hline \multirow[t]{2}{*}{ Ambrosia beetles ${ }^{\mathrm{a}}$} & & Australia and USA & $\begin{array}{l}\text { (Wylie et al. 2008; Bashford 2008; } \\
\text { Miller and Rabaglia 2009) }\end{array}$ \\
\hline & Scolytidae & & \\
\hline Bark beetles $^{\mathrm{a}}$ & & $\begin{array}{l}\text { Australia, USA and } \\
\text { French Pyrenees }\end{array}$ & $\begin{array}{l}\text { (Bashford 2008; Miller and Rabaglia 2009; } \\
\text { Fettig et al. 2004; Aukema et al. 2000b; } \\
\text { Hayes et al. 2008; Gaylord et al. 2006; } \\
\text { Bouget et al. 2009) }\end{array}$ \\
\hline Dendroctonus valens & & China and USA & (Sun et al. 2003; Erbilgin and Raffa 2002) \\
\hline Ips grandicollis $^{\mathrm{a}}$ & & Australia and USA & (Erbilgin and Raffa 2002) \\
\hline I. pini & & USA & (Erbilgin and Raffa 2002) \\
\hline I. typographus ${ }^{\mathrm{a}}$ & & $\begin{array}{l}\text { Italy, Norway, Slovenia } \\
\text { and Sweden }\end{array}$ & $\begin{array}{l}\text { (Jurc et al. 2006; Faccoli and Stergulc 2006; } \\
\text { 2004; Schlyter and Lundgren 1993; } \\
\text { Weslien 1992; Weslien and Schroeder } \\
\text { 1999) }\end{array}$ \\
\hline Manarthrum mali & & Italy & (Kirkendall et al. 2008) \\
\hline Pityogenes chalcographus ${ }^{\mathrm{a}}$ & & Slovenia & (Jurc et al. 2006) \\
\hline Tomicus destruens & & Europe and North Africa & (Gallego et al. 2008) \\
\hline
\end{tabular}

Diprionidae

Neodiprion sertifer ${ }^{\mathrm{a}}$

Wood boring insects

Lepidoptera

Dendrolimus punctatus

Siricidae
Mainly Scolytidae,

Cerambycidae

(Pajares et al. 2004; Ibeas et al. 2007)

(Nakamuta et al. 1997)

(Sweeney et al. 2006)

(Sweeney et al. 2006)

(Sweeney et al. 2006)

(Kendrick and Raffa 2006)

(Erbilgin and Raffa 2002)

(Rieske 2000)

(Erbilgin and Raffa 2002)

(Erbilgin and Raffa 2002)

Wylie et al. 2008; Bashford 2008;

Miller and Rabaglia 2009)

Bashford 2008; Miller and Rabaglia 2009;

Fettig et al 2004; Aukema et al. 2000b;

Hayes et al. 2008; Gaylord et al. 2006;

(Sun et al. 2003; Erbilgin and Raffa 2002)

(Erbilgin and Raffa 2002)

Erbilgin and Raffa 2002)

(Kirkendall et al. 2008)

(Gallego et al. 2008)

Finland, Japan, Europe and USA

(Anderbrant et al. 2000; Lyytikäinen-Saarenmaa et al. 2006; Goyer 1991)

USA

(Costello et al. 2008)

Lasiocampidae

(Zhang et al. 2003) 
Table 1 (continued)

\begin{tabular}{|c|c|c|c|}
\hline Insect $^{\mathrm{a}}$ & Family & Country & Reference \\
\hline \multirow[t]{2}{*}{ Malacosoma disstria $^{\mathrm{a}}$} & & North America & $\begin{array}{l}\text { (Jones et al. 2009; Goyer 1991; Schmidt } \\
\text { and Roland 2003) }\end{array}$ \\
\hline & Lymantriidae & & \\
\hline Euproctis chrysorrhea & & USA & (Khrimian et al. 2008) \\
\hline Lymantria dispar ${ }^{\mathrm{a}}$ & & $\begin{array}{l}\text { Australia, Britain, New } \\
\text { Zealand and North America }\end{array}$ & $\begin{array}{l}\text { (Thorpe et al. 2007a; Cannon et al. 2004; } \\
\text { Leonhardt et al. 1996) }\end{array}$ \\
\hline L. monacha & & Europe and North America & $\begin{array}{l}\text { (Morewood et al. 2000; Morewood } \\
\text { et al. 1999) }\end{array}$ \\
\hline \multirow[t]{2}{*}{ Orgyia pseudotsugata $^{\mathrm{a}}$} & & Canada & (Otvos and Shepherd 1991) \\
\hline & Thaumetopoeidae & & \\
\hline \multirow[t]{2}{*}{ Thaumetopoea pityocampa } & & France, Italy and Portugal & (Jactel et al. 2006a) \\
\hline & Tortricidae & & \\
\hline Choristoneura conflictana & & Canada & (Jones et al. 2009) \\
\hline C. rosaceana & & Canada & (Delisle 1992) \\
\hline Rhyacionia frustrana ${ }^{\mathrm{a}}$ & & USA & (Asaro et al. 2004) \\
\hline
\end{tabular}

${ }^{\text {a }}$ Systems where the knowledge is applied for monitoring

examples of kairomone monitoring include those used to monitor populations of the biological control agent Rhizophagus grandis, a species-specific predator of the Eurasian spruce bark beetle Dendroctonus micans (Meurisse et al. 2008). Kairomone attractants have also been used to monitor populations of the recently introduced European pine shoot beetle, Tomicus piniperda, infesting pine trees in North America (Poland et al. 2004). While certain volatiles have been found to be broadly applicable for this purpose, species- or groupspecific kairomone baits have also been developed to detect and monitor pest populations (Erbilgin et al. 2007; Wainhouse 2005). For the detection of numerous forestry pests in the Northern Hemisphere, single component lures were found to be effective, both in native and invaded non-native ranges, such as in the case of the red turpentine beetle, Dendroctonus valens, in both North America and China (Erbilgin et al. 2007).

Pheromone-baited traps can be more effective in monitoring pests than kairomone baits because of the highly specific nature of pheromonal attraction. This is especially true for emerging pests that are present in relatively low numbers (Hosking et al. 2003). Extensive pheromone-baited trap networks, therefore, have been set up throughout the world to aid in the detection, monitoring and management of serious forest pests. Examples include the trap network established throughout Europe to aid in the detection and monitoring of the spruce bark beetle, Ips typographus, and the bark beetle, Pityogenes chalcographus (Kelly 1990; Vité and Baader 1990). Furthermore, outbreaks of the pine sawfly, Neodiprion sertifer, in Europe, and the Douglas-fir tussock moth, Orgyia pseudotsugata, in the United States, have also been monitored using sex pheromones (Grant 1991; Lyytikäinen-
Saarenmaa et al. 2006; Lyytikäinen-Saarenmaa et al. 1999; Daterman et al. 2004).

An example of one of the largest pheromone-baited trap networks for a forestry pest is that used for the detection and eradication of the Gypsy moth, Lymantria dispar. In this network, roughly $130,000-150,000$ traps are placed within and ahead of the leading edge dispersal zone throughout nine states of the United States of America (Tobin et al. 2007; Mayo et al. 2003; Tobin et al. 2004). Early detection allows for the targeted eradication of small, isolated $L$. dispar populations ahead of the leading zone. This in turn prevents the coalescence of these populations into larger more viable populations and significantly slows the spread of the moth (Tobin et al. 2007; Liebhold and Tobin 2006; Mayo et al. 2003). This trap network guides management decisions for isolated $L$. dispar populations. The detection of isolated populations results in the implementation of several management approaches to ensure their eradication, including mating disruption, mass trapping, sterile male release and the spraying of microbial or chemical pesticides. The above examples of trap monitoring emphasise the point that monitoring using semiochemicals can form an integral part of some of the largest IPM systems, allowing for the detection and assessments of the impact and range of forest pest species.

\subsection{Control}

Semiochemicals have been used in direct applications for control of some forest pest species. Their ability to attract or repel, enhance or inhibit the action of other chemicals has been shown to be extremely powerful for controlling insect 
pests (Table 2). Actions for which such semiochemicals are used include mass trapping, mating disruption and/or deterring pests from food and oviposition sites (Agelopoulos et al. 1999). Deterring pests using interruptant semiochemicals such as anti-aggregation pheromones significantly reduced infestations of trees by the Mountain pine beetle, Dendroctonus ponderosae (Gillette et al. 2009a; Shea et al. 1992), Southern pine beetle, Dendroctonus frontalis (Sullivan et al. 2007) and other bark beetles, Ips typographus and Ips perturbatus (Graves et al. 2008; Jakuš et al. 2003). Antiaggregation pheromones have also been used to control outbreaks of the Douglas-fir beetle, Dendroctonus pseudotsugae (Gillette et al. 2009b; Werner et al. 2006). Mass trapping using aggregation pheromones has been successfully applied to enhance the control of, for example, bark beetles in various Northern Hemisphere forest plantations (Drumont et al. 1992; Stock et al. 1994; Schlyter et al. 2001; Wainhouse 2005). Aggregation pheromones are, for example, used to attract the beetles to felled trees rather than living trees, concentrating their reproduction on the trap trees and allowing these trees to be treated or removed prior to the emergence of the insect broods (Werner et al. 2006; Agelopoulos et al. 1999). Mass trapping with pheromones targeting the black pine bast scale Matsucoccus thunbergianae has also been undertaken in Korea, although there have been no reports of this pheromone being used subsequent to its development (Boo and Park 2005).

Mating disruption using semiochemicals in the form of sex pheromones has been most successfully applied to control Lepidopteran pests. Examples in forestry include mating

Table 2 Examples of semiochemical research and application for control of pests in forestry and other environments (e.g. urban high-risk entry points)

\begin{tabular}{|c|c|c|c|}
\hline Insect pest ${ }^{\mathrm{a}}$ & Family & Country & Reference \\
\hline \multicolumn{4}{|l|}{ Coleoptera } \\
\hline & Cerambycidae & & \\
\hline \multirow[t]{2}{*}{ Monochamus galloprovincialis } & & Spain & (Ibeas et al. 2007) \\
\hline & Scarabaeidae & & \\
\hline \multirow[t]{2}{*}{ Hylamorpha elegans } & & & (Quiroz et al. 2007) \\
\hline & Scolytidae & & \\
\hline Bark beetles $^{\mathrm{a}}$ & & USA & (Aukema et al. 2000a) \\
\hline Dendroctonus frontalis & & USA & \\
\hline D. ponderosae $e^{\mathrm{a}}$ & & USA & (Gillette et al. 2009a; Shea et al. 1992) \\
\hline D. pseudotsugae & & USA & (Gillette et al. 2009b) \\
\hline D. valens & & China and USA & (Sun et al. 2003; Rappaport et al. 2001) \\
\hline Dryocoetes confuses & & Canada & (Stock et al. 1994) \\
\hline Gnathotrichus sulcatus $^{\mathrm{a}}$ & & Canada & (Lindgren and Fraser 1994) \\
\hline Ips sexdentatus & & Spain & (Romón et al. 2007) \\
\hline I. typographus ${ }^{\mathrm{a}}$ & & $\begin{array}{l}\text { Belgium, Italy, Poland, Slovakia } \\
\text { and Sweden }\end{array}$ & $\begin{array}{l}\text { (Zhang and Schlyter 2003; Drumont et al. } \\
\text { 1992; Faccoli and Stergulc 2008) }\end{array}$ \\
\hline Pityophthorus pubescens & & Spain & (Romón et al. 2007) \\
\hline Tomicus spp. & & China & (Sun et al. 2005) \\
\hline Trypodendron lineatum ${ }^{\mathrm{a}}$ & & Canada & (Lindgren and Fraser 1994) \\
\hline \multicolumn{4}{|l|}{ Hemiptera } \\
\hline & Margarodidae & & \\
\hline Matsucoccus feytaudi & & Corsica & (Jactel et al. 2006b) \\
\hline Elatophilus nigricornis & & Corsica & (Jactel et al. 2006b) \\
\hline \multicolumn{4}{|l|}{ Lepidoptera } \\
\hline & Lasiocampidae & & \\
\hline \multirow[t]{2}{*}{ Malacosoma $s p^{\mathrm{a}}$} & & USA & (Fitzgerald 2008) \\
\hline & Lymantriidae & & \\
\hline Lymantria dispar ${ }^{\mathrm{a}}$ & & Britain and North America & $\begin{array}{l}\text { (Thorpe et al. 2007a; Cannon et al. 2004; } \\
\text { Leonhardt et al. 1996) }\end{array}$ \\
\hline \multirow[t]{2}{*}{ Orgyia thyellina ${ }^{\mathrm{a}}$} & & New Zealand & (Hosking et al. 2003) \\
\hline & Sesiidae & & \\
\hline Paranthrene robiniae & & USA & (Brown et al. 2006) \\
\hline
\end{tabular}

${ }^{\mathrm{a}}$ Systems where the knowledge is applied for control 
disruption of Eucosma sonomana and Rhyacionia zozana for several weeks after pheromone application, resulting in a population reduction of two thirds for each of the separate years studied (Gillette et al. 2006). Sex pheromones used for mating disruption were shown to reduce isolated gypsy moth, $L$. dispar, populations by $90 \%$, eliminating reproduction in these isolated populations beyond the leading edge of this pest (Thorpe et al. 1999, 2007b).

\section{Potential use of semiochemicals in Southern Hemisphere plantations}

Although semiochemical research has been undertaken for various insects in the tropics and Southern Hemisphere, there are few examples of this approach being used in intensively managed forestry plantations. The perceived high cost of discovery, development and application of semiochemicals for monitoring and/or control programmes has been suggested as the main reason for their minimal use in mainly non-native tree species forest plantations of the Southern Hemisphere and tropics (Brockerhoff et al. 2006a; Rodríguez and Niemeyer 2005). This is despite the already large areas and expected expansion of this region's intensively managed forest plantations (Sedjo 1999; Carle and Holmgren 2008; FAO 2011). A lack of research capacity is another reason for the minimal use of semiochemicals in this region, although recent efforts are being made in several countries to build capacity in this area. Thus, only 11 of the 429 scientific publications considered in this evaluation were from the Southern Hemisphere, with eight publications treating the development of the technology and only three focussed on its application.

Semiochemical research and development undertaken in the Northern Hemisphere has been applied in Southern Hemisphere forest plantation situations. For example, the Australian and New Zealand governments, as well as some private companies are using semiochemicals to monitor the presence of quarantine pests in high-risk areas such as seaports and airports, as well as in forests located close to these areas (Cole 2005; Brockerhoff et al. 2006a; Wylie et al. 2008). Extensive pheromone-trapping programmes for the Gypsy moth have been established in high-risk areas in New Zealand and Australia to serve as early warning systems to mitigate the risk of successful introductions (Cole 2005). This system proved highly effective in 2003 in New Zealand when a single male moth was detected in the city of Hamilton and intensive trapping was then used as part of the subsequent eradication campaign (MAF Biosecurity New Zealand 2008). In several Australian states, pheromone traps are also used to monitor the occurrence and population size of the exotic bark beetle Ips grandicollis in forest plantations (Bashford 2008). A national surveillance network was implemented in New Zealand by the Ministry of Agriculture and Forestry to detect exotic wood borers and bark beetles using pheromone and kairomone-baited traps (Brockerhoff et al. 2006a), and a similar trapping system has been used in several Australian states at high-risk sites since 2005 (Wylie et al. 2008). Results from both countries indicate that kairomone-baited traps placed in high-risk areas successfully trap both native and exotic Scolytidae and Cerambycidae.

An example of a strategy developed in the Southern Hemisphere using semiochemical technology from Northern Hemisphere is that for Sirex wood wasp monitoring. Here, within the intensively managed forestry plantations composed of non-native tree species, intentionally damaged trees, or trap trees, have been used to monitor the pest, because these trees are more attractive to Sirex than healthy surrounding trees (Neumann et al. 1982; Madden and Irvine 1971). In addition, Siricids in these trap trees are used as either a source of eggs and larvae on which wasp parasitoids such as Ibalia leucospoides and Megarhyssa nortoni can breed or for the application of the parasitic nematode, Deladenus siricidicola, (Madden and Irvine 1971; Neumann et al. 1982; Carnegie et al. 2005). Currently, various pine volatiles are being investigated as potential lures for traps, as an alternative to trap trees, for monitoring spread of Sirex noctilio in Australia and the United States of America (B. Slippers and B.P. Hurley, personal communication). Since 2007, a national network of monitoring traps using kairomone lures, simulating stressed pine trees, has been established across the South African non-native tree species commercial forestry plantation resource (P. Croft, personal communication). In this case, it is anticipated that monitoring Sirex ahead of the invasion front will allow for the early detection and swift release of biological control agents in newly invaded areas.

As suggested above, novel semiochemical development in intensively managed forestry plantations has been rather limited in the Southern Hemisphere. One of the first examples was the determination of the sex pheromone for the Pine Emperor moth, Nudaurelia cytherea cytherea, in South Africa (Henderson et al. 1972). Other more recent examples include the determination in New Zealand of the sex pheromone of the gum leaf skeletoniser Uraba lugens, an invasive eucalypt lepidopteran herbivore (Gibb et al. 2008), and of its subsequent use in predicting the moth's potential distribution and deployment as a monitoring tool as part of an incursion management programme (Kriticos et al. 2007; Suckling et al. 2005). In Australia, the sex pheromone of the Autumn gum moth, Mnesampela privata, has also been determined (Steinbauer et al. 2004; Walker et al. 2007) and shows potential as an effective population monitoring tool to be used in eucalypt plantation IPM in southern Australia (Östrand et al. 2007; Walker et al. 2007). 
Partnerships between governments, universities and commercial forestry companies can contribute to address the lack of research on the use of semiochemicals in Southern Hemisphere forestry plantations. An example is the collaborative programme in Chile where pheromones were identified and synthesised to monitor populations of the pine shoot moth, Rhyacionia buoliana (Rodríguez and Niemeyer 2005). Australian and South African researchers at both government research institutions and universities have begun to explore the potential to use sex pheromones to control cossid wood moths. These insects, for example, the giant wood moth Endoxyla cinereus and Culama wood moth Culama australis in Australia and the goat moth Coryphodema tristis in South Africa that kill trees or lower timber value in commercial eucalypt plantations (Lawson et al. 2008). A sex pheromone formulation for C. australis was successfully tested in the field in Australia in 2008-2009 (Lawson, unpublished results). In addition, Australian researchers have begun to consider the potential to manage native Eucalyptus tortoise beetles in the genera Paropsisterna and Paropsis in commercially managed Eucalyptus plantations using plant volatiles to enhance attraction to lethal trap trees on plantation edges (Elek 2009).

\section{Conclusions}

In this review, we reflect on the growing and effective use of semiochemicals to detect, monitor and control many forest pest species in the Northern Hemisphere. Despite their proven potential, however, their adoption in Southern Hemisphere intensively managed forestry plantations has been slow. In our view, the most likely reason is a relatively small research capacity and a lack of funds to discover and develop semiochemicals in the Southern Hemisphere. Southern Hemisphere forest plantations will become increasingly valuable for fibre production and carbon sequestration, and there is thus an urgent need to develop and focus research capacity to develop specific semiochemical approaches for this sector.

Introduced pests are increasing in number and frequency in forest plantations of the Southern Hemisphere at an alarming rate (Wingfield et al. 2008, 2011). Consequently, there is a growing urgency to increase the efficiency of monitoring and to detect new arrivals as early as possible. Doing so will increase the likelihood of successful eradication and will contribute substantially to understanding the pathways of introduction. Semiochemical-baited traps are better suited to monitor insect occurrence than almost any other method used for this purpose, as has been shown for various insect pests in Southern Hemisphere countries such as New Zealand and Australia.
While early detection is important to address the growing number of introduced pests in Southern Hemisphere plantations, the extent of the problem is such that this is unlikely to be sufficient on its own. There is consequently also a need to increase the efficiency of control strategies to better use the limited resources available. Here too, semiochemical research can contribute by improving the accuracy of monitoring of dispersal and population levels for the pests. This is especially relevant given that the use of chemical pesticides is becoming less viable because they are expensive to apply over the large areas of expanding plantations. Applications of chemicals in forestry is also under pressure because of their toxicity and the consequent prohibition by forest sustainability certification agencies such as the Forestry Stewardship Council, which strives for low chemical usage and IPM systems (Rametsteiner and Simula 2003; Anonymous 2005a, b, c).

As semiochemical research is developed for Southern Hemisphere plantations in coming years, careful consideration will need to be given in choosing target insects and the forestry system in which they operate for semiochemical monitoring and control, because these methodologies are not necessarily suited to all candidate pest insects (e.g. as reviewed in Millar (2006) and El-Sayed et al. (2009)). It will be important to take these criteria into account when selecting insect targets so as to maximise the chances of success in future semiochemical research and development in forestry plantations. Early success stories will also give the industry increased confidence that semiochemical-based pest management is a viable option in plantation forestry. Developing semiochemicals for key pests will not only enable better monitoring and control but will also provide valuable tools for researchers to better understand their biology and ecology to serve as model systems for such research in Southern Hemisphere environments.

Acknowledgements Members of the Tree Protection Co-operative Programme (TPCP), the Department of Trade and Industry THRIP programme and the National Research Foundation (NRF) are thanked for financial support.

\section{References}

Agelopoulos N, Birkett MA, Hick AJ, Hooper AM, Pickett JA, Pow EM, Smart LE, Smiley DWM, Wadhams LJ, Woodcock CM (1999) Exploiting semiochemicals in insect control. Pestic Sci 55:225-235

Anderbrant O, Lofqvist J, Hogberg HE, Hedenstrom E, Baldassari N, Baronio P, Kolmakova G, Lyons B, Naito T, Odinokov V, Simandl J, Supatashvili A, Tai A, Tourianov R (2000) Geographic variation in the field response of male European pine sawflies, Neodiprion sertifer, to different pheromone stereoisomers and esters. Entomol Exp Appl 95:229-239

Anonymous (2005a) FSC pesticide policy. Forest Stewardship Council, Bonn, Germany 
Anonymous (2005b) FSC Pesticide Policy: proposed revisions. FSCDIS-01-006. Forest Stewardship Council, Bonn, Germany

Anonymous (2005c) Pesticide Action Network, U.K.. Review of the Forest Stewardship Council's pesticide indicators and thresholds. Forest Stewardship Council, Bonn, Germany

Asaro C, Cameron RS, Nowak JT, Grosman DM, Seckinger JO, Berisford CW (2004) Efficacy of wing versus delta traps for predicting infestation levels of four generations of the Nantucket pine tip moth (Lepidoptera: Tortricidae) in the Southern United States. Environ Entomol 33:397-404

Aukema BH, Dahlsten DL, Raffa KF (2000a) Exploiting behavioral disparities among predators and prey to selectively remove pests: maximizing the ratio of bark beetles to predators removed during semiochemically based trap-out. Environ Entomol 29:651-660

Aukema BH, Dahlsten DL, Raffa KF (2000b) Improved population monitoring of bark beetles and predators by incorporating disparate behavioral responses to semiochemicals. Environ Entomol 29:618-629

Bale JS, van Lenteren JC, Bigler F (2008) Biological control and sustainable food production. Phil Trans R Soc B 363:761-776. doi:10.1098/rstb.2007.2182

Bartell SM, Nair SK (2004) Establishment risks for invasive species. Risk Anal 24:833-845

Bashford R (2008) The development of static trapping systems to monitor for wood-boring insects in forestry plantations. Austral For 71:236-241

MAF Biosecurity New Zealand (2008) Gypsy moth (Lymantria dispar). Ministry of Agriculture and Fisheries. http://www.biosecurity.govt.nz/pests/gypsy-moth. Accessed 1 January 2010

Boo KS, Park KC (2005) Insect semiochemical research in Korea: overview and prospects. Appl Entomol Zool 40:13-29

Borden JH, Wilson IM, Gries R, Chong LJ, Pierce JHD, Gries G (1998) Volatiles from the bark of trembling aspen, Populus tremuloides Michx. (Salicaceae) disrupt secondary attraction by the mountain pine beetle, Dendroctonus ponderosae Hopkins (Coleoptera: Scolytidae). Chemoecology 8:69-75

Bouget C, Brustel H, Brin A, Valladares L (2009) Evaluation of window flight traps for effectiveness at monitoring dead woodassociated beetles: the effect of ethanol lure under contrasting environmental conditions. Agr Forest Entomol 11:143-152. doi:10.1111/j.1461-9563.2008.00400.x

Brockerhoff EG, Jones DC, Kimberley MO, Suckling DM, Donaldson T (2006a) Nationwide survey for invasive wood-boring and bark beetles (Coleoptera) using traps baited with pheromones and kairomones. Forest Ecol Manag 228:234-240. doi:10.1016/ j.foreco.2006.02.046

Brockerhoff EG, Liebhold AM, Jactel H (2006b) The ecology of forest insect invasions and advances in their management. Can J For Res 36:263-268

Brown JJ, Kittelson NT, Hannon ER, Walsh DB (2006) An endemic population of western poplar clearwing moths (Lepidoptera: Sesiidae) invades a monoculture of hybrid poplar. J Econ Entomol 99:771-779

Cannon RJC, Koerper D, Ashby S, Baker R, Bartlett PW, Brookes G, Burgess R, Cheek S, Evans HF, Hammon R, Head J, Nettleton G, Robinson J, Slawson D, Taylor MC, Tilbury CA, Ward M (2004) Gypsy moth, Lymantria dispar, outbreak in northeast London, 1995-2003. Int J Pest Manage 50:259-273. doi:10.1080/ 09670870412331284573

Carle J, Holmgren P (2008) Wood from planted forests: a global outlook 2005-2030. Forests Products Journal 58:6-18

Carnegie AJ, Eldridge RH, Waterson DG (2005) History and management of Sirex wood wasp in pine plantations in New South Wales, Australia. New Zeal J For Sci 35:3-24

Clarke S (2001) Review of operational IPM program for the southern pine beetle. Integrated Pest Manag Rev 6:293-301
Cole M (2005) Forest invasive species strategies in Australia. In: McKenzie P, Brown C, Jianghua S, Jian W (eds) The unwelcome guests. Proceedings of the Asia-Pacific Forest Invasive Species Conference, Kunming, Yunnan Province, China, 2003. FAO, Bangkok, pp 59 - 77

Costello SL, Negron JF, Jacobi WR (2008) Traps and attractants for wood-boring insects in ponderosa pine stands in the Black Hills, South Dakota. J Econ Entomol 101:409-420

Daterman GE, Wenz JM, Sheehan KA (2004) Early warning system for Douglas-fir tussock moth outbreaks in the western United States. West J Appl For 19:232-241

DeBach P (1974) Biological control by natural enemies. Cambridge University Press, Great Britain

Delisle J (1992) Monitoring the seasonal male flight activity of Choristoneura rosaceana (Lepidoptera: Tortricidae) in Eastern Canada using virgin females and several different pheromone blends. Environ Entomol 21:1007-1012

Drumont A, Gonzalez R, Dewindt N, Gregoire JC, Deproft M, Seutin E (1992) Semiochemicals and the integrated management of Ips typographus (L) (Col, Scolytidae) in Belgium. J Appl Ent 114:333-337

Elek J (2009) Testing the efficacy of lethal trap trees. CRC for Forestry. http://www.crcforestry.com.au/view/index.aspx?id=45379. Accessed 1/7/2010

El-Sayed AM, Suckling DM, Byers JA, Jang EB, Wearing CH (2009) Potential of lure and kill in long-term pest management and eradication of invasive species. J Econ Entomol 102:815-835

Erbilgin N, Raffa KF (2002) Association of declining red pine stands with reduced populations of bark beetle predators, seasonal increases in root colonizing insects, and incidence of root pathogens. Forest Ecol Manag 164:221-236

Erbilgin N, Mori SR, Sun JH, Stein JD, Owen DR, Merrill LD, Campos Bolaños R, Raffa KF, Méndez Montiel T, Wood DL, Gillette NE (2007) Response to host volatiles by native and introduced populations of Dendroctonus valens (Coleoptera: curculionidae, Scolytinae) in North America and China. J Chem Ecol 33:131-146

Faccoli M, Stergulc F (2004) Ips typographus (L.) pheromone trapping in south Alps: spring catches determine damage thresholds. J Appl Entomol 128:307-311. doi:10.1111/j.1439-0418.2004.00848.307311

Faccoli M, Stergulc F (2006) A practical method for predicting the short-time trend of bivoltine populations of Ips typographus (L.) (Col., Scolytidae). J Appl Entomol 130:61-66

Faccoli M, Stergulc F (2008) Damage reduction and performance of mass trapping devices for forest protection against the spruce bark beetle, Ips typographus (Coleoptera: Curculionidae: Scolytinae). Ann For Sci 65:301-309

FAO (2007) State of the world's forests 2007. Food and Agriculture Organization of the United Nations, Rome

FAO (2011) State of the world's Forests 2011. Food and Agriculture Organization of the United Nations, Rome

Fettig CJ, Shea PJ, Borys RR (2004) Seasonal flight patterns of four bark beetle species (Coleoptera: Scolytidae) along a latitudinal gradient in California. Pan-Pacific Entomologist 80:4-17

Fitzgerald TD (2008) Use of pheromone mimic to cause the disintegration and collapse of colonies of tent caterpillars (Malacosoma spp.). J Appl Entomol 132:451-460. doi:10.1111/j.14390418.2008.01286.x

Gallego D, Galian J, Diez JJ, Pajares JA (2008) Kairomonal responses of Tomicus destruens (Col., Scolytidae) to host volatiles alphapinene and ethanol. J Appl Entomol 132:654-662. doi:10.1111/ j.1439-0418.2008.01304.x

Gaylord ML, Kolb TE, Wallin KF, Wagner MR (2006) Seasonality and lure preference of bark beetles (Curcullionidae: Scolytinae) and associates in a Northern Arizona ponderosa pine forest. Environ Entomol 35:37-47 
Gibb AR, Suckling DM, Fielder S, Bunn B, Jamieson LE, Larsen ML, Walter GH, Kriticos DJ (2008) Major sex pheromone components of the Australian gum leaf skeletonizer Uraba lugens: (10E,12Z)hexadecadien-1-yl acetate and (10E,12Z)-hexadecadien-1-ol. J Chem Ecol 34:1125-1133. doi:10.1007/s10886-008-9523-2

Gillette NE, Stein JD, Owen DR, Webster JN, Mori SR (2006) Pheromone-based disruption of Eucosma sonomana and Rhyacionia zozana (Lepidoptera: Tortricidae) using aerially applied microencapsulated pheromone. Can J For Res 36:361-368

Gillette NE, Erbilgin N, Webster JN, Pederson L, Mori SR, Stein JD, Owen DR, Bischel KM, Wood DL (2009a) Aerially applied verbenone-releasing laminated flakes protect Pinus contorta stands from attack by Dendroctonus ponderosae in California and Idaho. Forest Ecol Manag 257:1405-1412

Gillette NE, Mehmel CJ, Webster JN, Mori SR, Erbilgin N, Wood DL, Stein JD (2009b) Aerially applied methylcyclohexenone-releasing flakes protect Pseudotsuga menziesii stands from attack by Dendroctonus pseudotsugae. Forest Ecol Manag 257:1231-1236

Goyer RA (1991) Integrated pest management of forest defoliators in the South eastern United States. Forest Ecol Manag 39:131-142

Grant GG (1991) Development and use of pheromones for monitoring lepidopteran forest defoliators in North America. Forest Ecol Manag 39:153-162

Graves AD, Holsten EH, Ascerno ME, Zogas KP, Hard JS, Huber DPW, Blanchette RA, Seybold SJ (2008) Protection of spruce from colonization by the bark beetle, Ips perturbatus, in Alaska. Forest Ecol Manag 256:1825-1839

Hayes CJ, DeGomez TE, Clancy KN, Williams KK, McMillin JD, Anhold JA (2008) Evaluation of funnel traps for characterizing the bark beetle (Coleoptera: Scolytidae) communities in ponderosa pine forests of north-central Arizona. J Econ Entomol 101:1253-1265

Henderson HE, Warren FL, Augustyn OPH, Burger BV, Schneider DF, Boshoff PR, Spies HSC, Geertsema H (1972) Sex-pheromones. cis-Dec-5-en-1-yl 3-methylbutanoate as the pheromone from the pine emperor moth (Nudaurelia cytherea cytherea Fabr.). J Chem Soc Chem Commun 11:686-687

Hosking G, Clearwater J, Handiside J, Kay M, Ray J, Simmons N (2003) Tussock moth eradication - a success story from New Zealand. Int J Pest Manage 49:17-24

Hughes (1974) Myrcene: a precursor of pheromones in Ips beetles. J Insect Physiol 20:1271-1275

Hurley BP, Slippers B, Wingfield MJ (2007) A comparison of control results for the alien invasive woodwasp, Sirex noctilio, in the southern hemisphere. Agr Forest Entomol 9:159-171

Ibeas F, Gallego D, Diez JJ, Pajares JA (2007) An operative kairomonal lure for managing pine sawyer beetle Monochamus galloprovincialis (Coleoptera: Cerymbycidae). J Appl Entomol 131:1320. doi:10.1111/j.1439-0418.2006.01087.x

Jactel H, Menassieu P, Vétillard F, Barthélémy B, Piou D, Frérot B, Rousselet J, Goussard F, Branco M, Battisti A (2006a) Population monitoring of the pine processionary moth (Lepidoptera: Thaumetopoeidae) with pheromone-baited traps. Forest Ecol Manag 235:96-106

Jactel H, Menassieu P, Vetillard F, Gaulier A, Samalens JC, Brockerhoff EG (2006b) Tree species diversity reduces the invasibility of maritime pine stands by the bast scale, Matsucoccus feytaudi (Homoptera: Margarodidae). Can J For Res 36:314-323

Jakuš R, Schlyter F, Zhang QH, Blaženec M, Vaverčák R, Grodzki W, Brutovský D, Lajzová E, Turčáni M, Bengtsson M, Blum Z, Gregoiré JC (2003) Overview of development of an antiattractant based technology for spruce protection against Ips typographus: from past failures to future success. Anzeiger für Schädlingskunde 76:89-99

Jones BC, Roland J, Evenden ML (2009) Development of a combined sex pheromone-based monitoring system for Malacosoma disstria
(Lepidoptera: Lasoicampidae) and Choristoneura conflictana (Lepidoptera: Tortricidae). Environ Entomol 38:459-471

Jurc M, Perko M, Dzeroski S, Demsar D, Hrasovec B (2006) Spruce bark beetles (Ips typographus, Pityogenes chalcographus, Col.: Scolytidae) in the Dinaric mountain forests of Slovenia: monitoring and modeling. Ecol Model 194:219-226. doi:10.1016/ j.ecolmodel.2005.10.014

Kelly DR (1990) Insect semiochemicals. Chem Br 26:124-127

Kendrick AP, Raffa KF (2006) Sources of insect and plant volatiles attractive to cottonwood leaf beetles feeding on hybrid poplar. J Chem Ecol 32:2585-2594. doi:10.1007/s10886-006-9184-y

Khrimian A, Lance DR, Schwarz M, Leonhardt BA, Mastro VC (2008) Sex pheromone of browntail moth, Euproctis chrysorrhea (L.): synthesis and field deployment. J Agr Food Chem 56:2452-2456. doi:10.1021/jf073161w

Kirkendall LR, Dal Cortivo M, Gatti E (2008) First record of the ambrosia beetle, Monarthrum mali (Curculionidae, Scolytinae) in Europe. J Pest Sci 81:175-178. doi:10.1007/s10340-008-0196-y

Kolar CS, Lodge DM (2001) Progress in invasion biology: predicting invaders. Trends Ecol Evol 16:199-204

Kriticos DJ, Potter KJB, Alexander NS, Gibb AR, Suckling DM (2007) Using a pheromone lure survey to establish the native and potential distribution of an invasive Lepidopteran, Uraba lugens. J Appl Ecol 44:853-863

Lawson SA, Moore CJ, Slippers B, Hurley BP, Wingfield MJ (2008) Isolation of sex pheromones of cossid wood moth (Lepidoptera: Cossidae) pests of Eucalypt plantations in Australia and South Africa. Paper presented at the IUFRO working group 7.3.00. Recent advances in forest entomology, Pretoria, South Africa,

Leonhardt BA, Mastro VC, Leonard DS, McLane W, Reardon RC, Thorpe KW (1996) Control of low-density gypsy moth (Lepidoptera: Lymantriidae) populations by mating disruption with pheromone. J Chem Ecol 22:1255-1272

Liebhold A, Tobin P (2006) Growth of newly established alien populations: comparison of North American Gypsy Moth colonies with invasion theory. Popul Ecol 48:253-262

Lindgren BS, Fraser RG (1994) Control of ambrosia beetle damage by mass trapping at a dryland log sorting area in British Columbia. Forest Chron 70:159-163

Lyytikäinen-Saarenmaa P, Anderbrant O, Löfqvist J, Hedenström E, Högberg H (1999) Monitoring European pine sawfly population densities with pheromone traps in young pine plantations. Forest Ecol Manag 124:113-121

Lyytikäinen-Saarenmaa P, Varama M, Anderbrant O, Kukkola M, Kokkonen AM, Hedenstrom E, Hogberg HE (2006) Monitoring the European pine sawfly with pheromone traps in maturing Scots pine stands. Agr Forest Entomol 8:7-15

Madden JL, Irvine CJ (1971) The use of lure trees for the detection of Sirex noctilio in the field. Austral For:164-166

Mayo JH, Straka TJ, Leonard DS (2003) The cost of slowing the spread of the gypsy moth (Lepidoptera: Lymantriidae). J Econ Entomol 96:1448-1454

Meurisse N, Couillien D, Grégoire J (2008) Kairomone traps: a tool for monitoring the invasive spruce bark beetle Dendroctonus micans (Coleoptera: Scolytinae) and its specific predator, Rhizophagus grandis (Coleoptera: Monotomidae). J Appl Ecol 45:537-548

Millar J (2006) Editors' Preface (papers by J.R. Miller, L.J. Gut, F.M. de Lame, and L.L. Stelinski). J Chem Ecol 32:2085-2087

Miller DR (2006) Ethanol and (-)-alpha-pinene: attractant kairomones for some large wood-boring beetles in southeastern USA. J Chem Ecol 32:779-794. doi:10.1007/s10886-006-9037-8

Miller DR, Rabaglia RJ (2009) Ethanol and (-)-alpha-pinene: attractant kairomones for bark and ambrosia beetles in the Southeastern US. J Chem Ecol 35:435-448. doi:10.1007/s10886-009-9613-9

Morewood P, Gries G, Haussler D, Moller K, Liska J, Kapitola P, Bogenschutz H (1999) Towards pheromone-based detection of 
Lymantria monacha (Lepidoptera: Lymantriidae) in North America. Can Entomol 131:687-694

Morewood P, Gries G, Liska J, Kapitola P, Haussler D, Moller K, Bogenschutz H (2000) Towards pheromone-based monitoring of nun moth, Lymantria monacha (L.) (Lep., Lymantriidae) populations. J Appl Entomol 124:77-85

Nakamura K, Sone K, Ookuma H (1999) Modification of a commercial attraction trap for live trapping of Monochamus alternatus (Hope) adults (Coleoptera; Cerambycidae). Jpn J Appl Entomol Z 43:55-59

Nakamuta K, Leal WS, Nakashima T, Tokoro M, Ono M, Nakanishi M (1997) Increase of trap catches by a combination of male sex pheromones and floral attractant in longhorn beetle, Anaglyptus subfasciatus. J Chem Ecol 23:1635-1640

Neumann FG, Harris JA, Kassaby FY, Minko G (1982) An improved technique for early detection and control of the Sirex wood wasp in radiata pine plantations. Austral For 45:117-124

Norin T (2001) Pheromones and kairomones for control of pest insects. Some current results from a Swedish research program. Pure Appl Chem 73:607-612

Östrand F, Elek JA, Steinbauer MJ (2007) Monitoring autumn gum moth (Mnesampela privata): relationships between pheromone and light trap catches and oviposition in eucalypt plantations. Austral For 70:185-191

Otvos IS, Shepherd RF (1991) Integration of early virus treatment with a pheromone detection system to control Douglas-fir tussock moth, Orgyia pseudotsugata (Lepidoptera, Lymantriidae), populations at pre-outbreak levels. Forest Ecol Manag 39:143-151

Pajares JA, Ibeas F, Diez JJ, Gallego D (2004) Attractive responses by Monochamus galloprovincialis (Col., Cerambycidae) to host the bark beetle semiochemicals. J Appl Entomol 128:633-638

Peacock L, Worner SP (2008) Biological and ecological traits that assist in the establishment of alien invasive insects. N Z Plant Protect 61:1-7

Pimentel D, Acquay H, Biltonen M, Rice P, Silva M, Nelson J, Lipner V, Giordano S, Horowitz A, D'Amore M (1992) Environmental and economic costs of pesticide use. BioScience 42:750-760

Poland TM, de Groot P, Haack RA, Czokajlo D (2004) Evaluation of semiochemicals potentially synergistic to alpha-pinene for trapping the larger European pine shoot beetle, Tomicus piniperda (Col., Scolytidae). J Appl Entomol 128:639-644

Quiroz A, Palma R, Etcheverria P, Navarro V, Rebolledo R (2007) Males of Hylamorpha elegans Burmeister (Coleoptera: Scarabaeidae) are attracted to odors released from conspecific females. Environ Entomol 36:272-280

Rametsteiner E, Simula M (2003) Forest certification - an instrument to promote sustainable forest management? J Environ Manage 67:87-98

Rappaport NG, Owen DR, Stein JD (2001) Interruption of semiochemicalmediated attraction of Dendroctonus valens (Coleoptera: Scolytidae) and selected nontarget insects by verbenone. Environ Entomol 30:837-841

Rieske LK (2000) Pine weevil (Coleoptera: Curculionidae) population monitoring in Christmas trees using volatile host compounds. J Entomol Sci 35:167-175

Rodríguez LC, Niemeyer HM (2005) Integrated pest management, semiochemicals and microbial pest-control agents in Latin American agriculture. Crop Prot 24:615-623

Romón P, Iturrondobeitia JC, Gibson K, Lindgren BS, Goldarazena A (2007) Quantitative association of bark beetles with pitch canker fungus and effects of verbenone on their semiochemical communication in Monterey pine forests in Northern Spain. Environ Entomol 36:743-750

Roques A, Rabitsch W, Rasplus J, Lopez-Vaamonde C, Nentwig W, Kenis M (2008) Alien terrestrial invertebrates of Europe. In: DAISIE, The handbook of alien species in Europe. Berlin: Springer Science, pp 63-79
Schlyter F, Lundgren U (1993) Distribution of a bark beetle and its predator within and outside old-growth forest reserves - no increase of hazard near reserves. Scand J Forest Res 8:246-256

Schlyter F, Zhang Q-H, Liu G-T, Ji L-Z (2001) A successful case of pheromone mass trapping of the bark beetle Ips duplicatus in a forest island, analysed by 20 -year time-series data. Integrated Pest Management Reviews 6:185-196

Schmidt BC, Roland J (2003) Developing techniques for monitoring forest tent caterpillar populations using synthetic pheromones. Can Entomol 135:439-448

Sedjo RA (1999) The potential of high-yield plantation forestry for meeting timber needs: recent performance, future potentials, and environmental implications. New Forest 17:339-359

Sedjo RA (2000) The social and economic impacts of plantation forests. In: Krishnapillay B, Soepadmo E, Arshad NL et al. (eds) Forests and society: the role of research: XXI IUFRO World Congress, Kuala Lumpur, Malaysia, 7-12 August 2000. International Union of Forest Research Organization, pp 351-355

Shea PJ, McGregor MD, Daterman GE (1992) Aerial application of verbenone reduces attack of lodgepole pine by Mountain pine beetle. Can J For Res 22:436-441

Silverstein RM (1981) Pheromones: background and potential for use in insect pest control. Science 213:1326-1332

Smith RM, Baker RHA, Malumphy CP, Hockland S, Hammon RP, Ostojá-Starzewski JC, Collins DW (2007) Recent non-native invertebrate plant pest establishments in Great Britain: origins, pathways, and trends. Agr Forest Entomol 9:307-326

Steinbauer MJ, Ostrand F, Bellas TE, Nilsson A, Andersson F, Hedenstrom E, Lacey MJ, Schiestl FP (2004) Identification, synthesis and activity of sex pheromone gland components of the autumn gum moth (Lepidoptera: Geometridae), a defoliator of Eucalyptus. Chemoecology 14:217-223

Stock AJ, Borden JH, Pratt TL (1994) Containment and concentration of infestations of the western balsam bark beetle, Dryocoetes confusus (Coleoptera: Scolytidae), using the aggregation pheromone exo-brevicomin. Can J For Res 24:483-492

Stone C (2001) Reducing the impact of insect herbivory in eucalypt plantations through management of extrinsic influences on tree vigour. Austral Ecology 26:482-488

Suckling DM, Gibb AR, Dentener PR, Seldon DS, Clare GK, Jamieson L, Baird D, Kriticos DJ, El-Sayed AM (2005) Uraba lugens (Lepidoptera: Nolidae) in New Zealand: pheromone trapping for delimitation and phenology. J Econ Entomol 98:1187-1192

Sullivan BT, Dalusky MJ, Wakarchuk Dm Berisford CW (2007) Field evaluations of potential aggregation inhibitors for the southern pine beetle, Dendroctonus frontalis (Coleoptera: Curculionidae). J Entomol Sci 42:139-149

Sun JH, Gillette NE, Miao ZW, Kang L, Zhang ZN, Owen DR, Stein JD (2003) Verbenone interrupts attraction to host volatiles and reduces attack on Pinus tabuliformis (Pinaceae) by Dendroctonus valens (Coleoptera: Scolytidae) in the People's Republic of China. Can Entomol 135:721-732

Sun JH, Clarke SR, Kang L, Wang HB (2005) Field trials of potential attractants and inhibitors for pine shoot beetles in the Yunnan province, China. Ann For Sci 62:9-12. doi:10.1051/forest:2004087

Sweeney J, Gutowski JM, Price J, De Groot P (2006) Effect of semiochemical release rate, killing agent, and trap design on detection of Tetropium fuscum (F.) and other longhorn beetles (Coleoptera: Cerambycidae). Environ Entomol 35:645-654

Thorpe KW, Mastro VC, Leonard DS, Leonhardt BA, McLane W, Reardon RC, Talley SE (1999) Comparative efficacy of two controlled-release gypsy moth mating disruption formulation. Entomol Exp Appl 90:267-277

Thorpe KW, Tcheslavskaia KS, Tobin PC, Blackbum LM, Leonard DS, Roberts EA (2007a) Persistent effects of aerial applications of 
disparlure on gypsy moth: trap catch and mating success. Entomol Exp Appl 125:223-229. doi:10.1111/j.1570-7458.2007.00613.x

Thorpe KW, van der Pers J, Leonard DS, Sellers P, Mastro VC, Webb RE, Reardon RC (2007b) Electroantennogram measurements of atmospheric pheromone concentration after aerial and ground application of gypsy moth mating disruptant. J Appl Entomol 131:146-152

Tobin PC, Sharov AA, Liebhold AM, Leonard DS, Roberts EA, Learn MR (2004) Management of the Gypsy Moth through a decision algorithm under the STS project. American Entomologist 50:200 209

Tobin PC, Whitmire SL, Johnson DM, Bjørnstad ON, Liebhold AM (2007) Invasion speed is affected by geographical variation in the strength of Allee effects. Ecol Lett 10:36-43

Vité JP, Baader E (1990) Present and future use of semiochemicals in pest management of bark beetles. J Chem Ecol 16:3031-3041

Wainhouse D (2005) Ecological methods in forest pest management. Oxford University Press, Oxford

Walker P, Allen GR, Davies N (2007) A new pheromone formulation to monitor autumn gum moth (Mnesampela privata). CRC for Forestry. http://www.crcforestry.com.au/view/index.aspx? id $=29304$. Accessed 7 January 2010

Werner RA, Holsten EH, Matsuoka SM, Burnside RE (2006) Spruce beetles and forest ecosystems in south-central Alaska: a review of 30 years of research. Forest Ecol Manag 227:195-206

Weslien J (1992) Monitoring Ips typographus populations and forecasting damage. J Appl Entomol 114:338-340

Weslien J, Schroeder LM (1999) Population levels of bark beetles and associated insects in managed and unmanaged spruce stands. Forest Ecol Manag 115:267-275
Wilson JRU, Dormontt EE, Prentis PJ, Lowe AJ, Richardson DM (2009) Something in the way you move: dispersal pathways affect invasion success. Trends Ecol Evol 24:136-144

Wingfield MJ (2003) Daniel McAlpine Memorial Lecture. Increasing threat of diseases to exotic plantation forests in the Southern Hemisphere: lessons from Cryphonectria canker. Australas Plant Path 32:133-139

Wingfield MJ, Slippers B, Hurley BP, Coutinho TA, Wingfield BD, Roux J (2008) Eucalypt pests and diseases: growing threats to plantation productivity. South For 70:139-144

Wingfield MJ, Roux J, Wingfield BD (2011) Insect pests and pathogens of Australian acacias grown as non-natives - an experiment in biogeography with far-reaching consequences. Divers Distrib 17:968-977

Wood DL (1982) The role of pheromones, kairomones and allomones in the host selection and colonization behavior of bark beetles. Annu Rev Entomol 27:411-446

Work T, McCullough D, Cavey J, Komsa R (2005) Arrival rate of nonindigenous insect species into the United States through foreign trade. Biol Invasions 7:323-332

Wylie FR, Griffiths M, King J (2008) Development of hazard site surveillance programs for forest invasive species: a case study from Brisbane, Australia. Austral For 71:229-235

Zhang QH, Schlyter F (2003) Redundancy, synergism, and active inhibitory range of non-host volatiles in reducing pheromone attraction in European spruce bark beetle Ips typographus. Oikos 101:299-310

Zhang AB, Wang ZJ, Tan SJ, Li DM (2003) Monitoring the masson pine moth, Dendrolimus punctatus (Walker) (Lepidoptera: Lasiocampidae) with synthetic sex pheromone-baited traps in Qianshan County, China. Appl Entomol Zool 38:177-186 